\title{
REVIEW OF CELLULAR AND SUBCELLULAR CHANGES IN THE CAMBIUM
}

\author{
Peter Prislan ${ }^{1,2,{ }^{*}, \text { Katarina Čufar }}{ }^{2}$, Gerald Koch ${ }^{3}$, Uwe Schmitt ${ }^{3}$ and \\ Jožica Gričar ${ }^{1}$
}

\author{
${ }^{1}$ Slovenian Forestry Institute, Večna pot 2, SI-1000 Ljubljana, Slovenia \\ ${ }^{2}$ Biotechnical Faculty, Department of Wood Science and Technology, University of Ljubljana, \\ Rožna dolina, Cesta VIII/34, SI-1000 Ljubljana, Slovenia \\ ${ }^{3}$ Thünen Institute of Wood Research, Leuschnerstraße 91, D-21031 Hamburg, Germany \\ *Corresponding author; e-mail: peter.prislan@gozdis.si
}

\begin{abstract}
The commonest approach to studying cambial productivity is conventional light microscopy, which is widely used in wood formation studies. The number of such studies has increased rapidly in the past decade, usually in order to elucidate the relationship between growth and environmental factors. However, some aspects of cambial seasonality are often overlooked or neglected. Observations with transmission electron microscopy provide a more detailed insight into changes occurring on the ultra-structural level in cambial cells. Criteria for defining cambial activity are not yet fully clarified, especially when observing it at different resolutions, i.e., on cellular, subcellular and ultrastructural levels. The goal of this review is to contribute to clarification of the terms mainly used, such as cambial dormancy, reactivation, activity, productivity and transition between different states, resting period and quiescence, which describe structural modifications of cambial cells during the various phases of their seasonal cycle. Based on our own cambium observations on adult beech trees growing at two different elevations, which were made with light and transmission electron microscopy, we discuss the influence of weather conditions on cambial activity and the advantage of the complementary use of different techniques and resolutions.
\end{abstract}

Keywords: Cambial activity, cambial cells, Fagus sylvatica, light microscopy, transmission electron microscopy, ultrastructural changes.

\section{INTRODUCTION}

Growth in plants takes place in specialised tissues, so-called meristems, which act as central control points for growth and development, receiving, integrating, responding to and broadcasting growth-regulating signals (Risopatron et al.2010). Two meristems are responsible for the growth of trees: apical (growth in length) and lateral (growth in girth) (Lachaud et al. 1999). Apical meristems produce primary tissues, whereas lateral meristems (i.e., vascular and cork cambium) contribute to the production of secondary tissues (Mauseth 2009). The vascular cambium develops from the procambium, which in turn is derived from parenchyma cells that have regained the capability to divide 
(Evert 2006). The cambium is a bifacial meristem because it produces xylem cells in the centripetal and phloem cells in the centrifugal direction (Larson 1994).

Cambial activity ensures the perennial life of trees through regular renewal of functional xylem and phloem (Plomion et al.2001). Moreover, cambial growth might be considered to be the tree's way of ensuring that its stem and branches have sufficient structural support and hydraulic conductivity to grow against gravity, while also providing for the needs of the root system (Savidge 2000b). The annual course of cambial activity is generally related to the alternation of cold and warm or dry and rainy seasons (Lachaud et al. 1999). In some climatic regions, i.e. tropics, cambial activity may continue throughout the year, whereas in temperate regions the activity of the cambium is usually periodical, subjected to the tree's internal regulation (genetic and hormonal) (Ursache et al . 2013) and environmental factors, such as temperature, precipitation, photoperiod and other biotic and abiotic influences (e.g. Wodzicki 2001; Evert 2006; Begum et al.2013).

Commonly, xylem production represents the major proportion of the tree's radial growth. In addition to the economic importance of wood, and partly also bark, wood increments provide an integral archive of factors affecting its formation before and/or during the time of cambial growth. Dendroclimatological and dendroecological studies, in combination with intra-annual observations of radial growth of trees, are thus useful in order better to understand climate-growth relationships (Čufar et al. 2008; Callado et al. 2013; Costa et al. 2013).

Although numerous investigations have been dedicated to the annual rhythm of cambial activity in various tree species, criteria for determining its activity are still not satisfactorily defined, especially in the case of observations (and their comparisons) at different levels, e.g., cellular, sub-cellular and ultra-structural levels (Frankenstein et al. 2005; Prislan et al. 2011; Rathgeber et al. 2011). When observing ultrastructure of cambial cells, for example, the onset of cambial activity can be easily defined when first mitotic figures and phragmoplasts are observed (Larson 1994; Farrar \& Evert 1997). However, changes in the ultrastructure of cells, which could also be considered as activity, occur before formation of phragmoplast, as a transition from the dormant to the active state (Farrar \& Evert 1997). In wood formation studies, phragmoplasts or mitotic figures cannot be observed due to different methodologies of sample preparation and observation. Therefore reactivation of the cambium is defined by an increase in number of cambial cells and the occurrence of newly formed xylem and phloem cells in early developmental stages (e.g., Gričar et al. 2006; Deslauriers et al. 2008). Rathgeber et al.(2011), who studied cambial phenology and xylem formation in Abies alba, pointed out that the number of cells in the cambium cannot be a precise indicator for its activity, because the increase in cell number may be insignificant. Consequently, the appearance of first enlarging xylem cells was considered as a more appropriate indicator for cambial reactivation (Rathgeber et al.2011). In contrast, Frankenstein et al . (2005) observed that initial earlywood vessels in ring porous Fraxinus excelsior were formed in the previous growing season and overwintered, and then started to differentiate prior to the onset of cambial cell divisions in spring.

Aims of this review are to: (i) highlight the latest findings on structural modifications in cambium that are related to its seasonal activity and cell production; (ii) exemplify 
them by our most recent observations on seasonal cellular and ultrastructural changes in cambium (Prislan et al. 2011) and phenological variation in cambial productivity (Prislan et al. 2013) carried out in Fagus sylvatica growing under different weather conditions and (iii) emphasise the differences in observations at the cellular and ultrastructural level in order to suggest a suitable terminology for determining the onset of cambial activity at different observational levels.

\section{STRUCTURE AND FUNCTION OF CAMBIUM}

The cambium is composed of highly vacuolated meristematic cells organised in radial files, which give rise to the secondary xylem and phloem. Theoretically, each radial file contains one initial cell, which remains in the meristem, as well as phloem and xylem mother cells, which are produced by the division of cambial initials (Larson 1994). Consequently, the term "cambium" is used to refer to cambial initials and "cambial zone" to the region of cambial initials and mother cells (Lachaud et al. 1999). Since the initials and mother cells of cambium are distinguished cytologically only by a small difference in length, most published data do not distinguish between the two cell types (e.g., Larson 1994; Savidge 2000b). The terms "cambial cells" and "cambium" will be used hereafter to denote all undifferentiated cells capable of division. Savidge (2000a) argued that every cambial cell could be equally competent and that cambium is maintained in response to basipetally transported auxin in conjunction with physical forces. The differential behaviour of cambial cells could be explained by changes in the micro-environment experienced by the genome within each cell (Savidge 1996).

While the main function of the cambium is cell division and setting out patterns for differentiation, similar to other meristems, several aspects are unique to vascular cambium. Unlike apical meristems, cambium is a complex tissue containing two morphologically distinct cell types: axially elongated fusiform cambial cells and somewhat isodiametrical ray cambial cells. These cells give rise to the axial and radial cells of the secondary xylem and phloem. The identity of cambial cells is determined by positional cues rather than by cell lineage, because inter-conversion between fusiform and ray cambial cells is a common phenomenon (e.g. Larson 1994; Mellerowicz et al. 2001). The balance in the number and distribution between fusiform and ray cambial cells is maintained by anticlinal divisions and by conversion of one kind of cell into the other. Fusiform cambial cells thus give rise to new cambial ray cells through transverse or oblique divisions, while ray cells elongate into fusiform ones through intrusive growth (Lachaud et al. 1999). Anticlinal (= radial and pseudotransverse), often also referred to as multiplicative, cell divisions ensure the increase in girth of the cambium (Fig. 1). Transverse and anticlinal divisions ensure the maintenance of cambial integrity, while periclinal (= tangential) divisions (also referred as additive divisions) give rise to new cells of xylem and phloem tissue (Larson 1994; Lachaud et al. 1999).

Most divisions of fusiform cambial cells are periclinal, in which new cells are added within a radial file towards either the secondary xylem or the secondary phloem (Catesson 1994). In relation to the functioning of the cambium, two aspects appear to be important for the cambial cell production: 1) the number of dividing cambial cells 

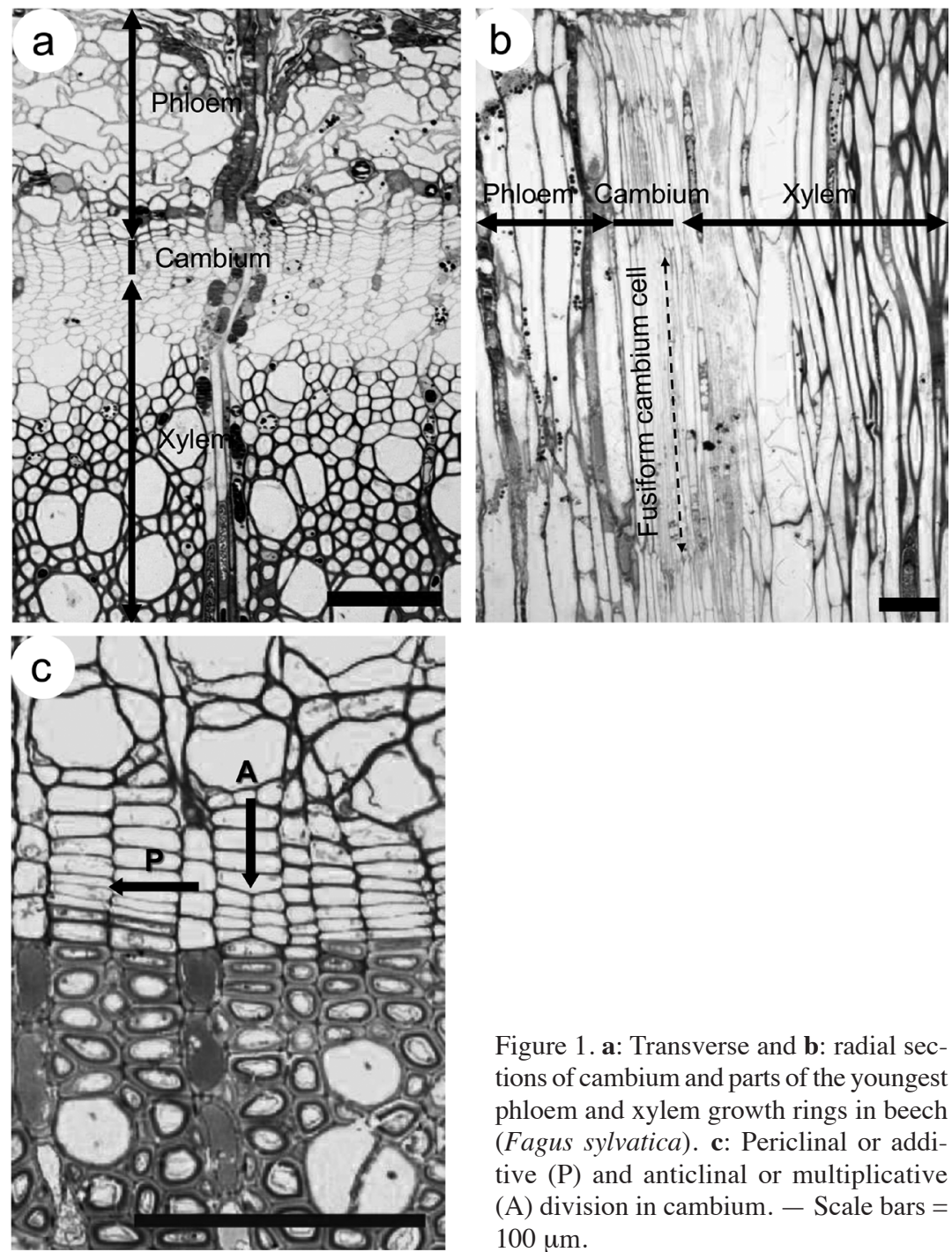

Figure 1. a: Transverse and $\mathbf{b}$ : radial sections of cambium and parts of the youngest phloem and xylem growth rings in beech (Fagus sylvatica). c: Periclinal or additive $(\mathrm{P})$ and anticlinal or multiplicative (A) division in cambium. - Scale bars $=$ $100 \mu \mathrm{m}$.

and how fast the newly formed derivatives are released from the meristematic regio and 2) the duration of the cell cycle. Both aspects may be individually targeted to maximise the rate of cell production on the xylem and phloem sides (Uggla et al. 1998; Mellerowicz et al. 2001).

Wood and phloem formation are not predetermined processes but are very plastic expressions of interactions between genotype and the environment (Savidge 2000b) and require positional information that coordinates the radial pattern of the developmental zones (Uggla et al. 1998). Both phloem and xylem are complex tissues, each containing more than one cell type, so cambial derivatives pass through successive stages of differentiation during the development of phloem or xylem (Savidge 2000b). Cell 
differentiation thus involves four major steps: cell expansion, followed by the ordered deposition of a thick multi-layered secondary cell wall and, in the case of sclerenchyma and tracheary elements, also cell wall lignification and cell death. Cambial cell production is normally more active on the xylem side, explaining the considerable disproportion existing between phloem and xylem tissue (Plomion et al. 2001). Fromm (2013) reported that most tree species have xylem to phloem ratios of between $4: 1$ and $10: 1$.

\section{SEASONAL CHANGES IN CAMBIAL CELLS}

In trees of temperate and cold climatic regions, cambial activity is seasonal and depends on a complex of interactions among intrinsic and extrinsic factors (Savidge 1996; Evert 2006). The dormant period starts immediately after the cessation of meristematic activity and lasts until the resumption of cell divisions (Lachaud et al. 1999). Winter dormancy is usually divided into two periods: 1) the resting period or physiological dormancy, which is driven endogenously and 2) quiescence or environmental dormancy, driven by environmental factors (Riding \& Little 1984). During the first 2 to 4 weeks of dormancy, the cambium is unable to produce new cells, even when conditions are favourable (resting period). The resting period terminates when the cambium gradually regains the ability to produce new xylem and phloem cells due to favourable environmental conditions (quiescent stage of dormancy).

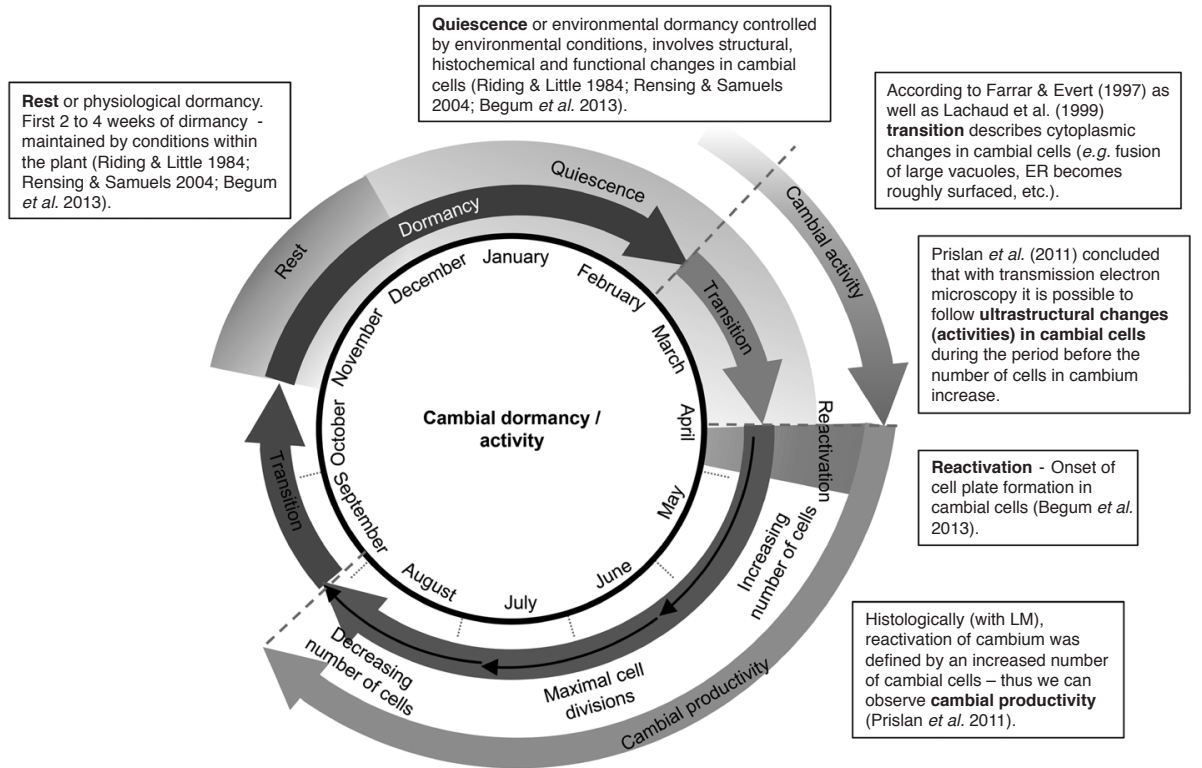

Figure 2. Schematic presentation of most commonly used terminology (proposed by various authors) in terms of cambial dormancy and activity, for the example of Fagus sylvatica trees growing at $400 \mathrm{~m}$ a.s.1. in Slovenia. 
The transition from resting to quiescence involves structural, histochemical and functional changes in cambial cells (Lachaud et al. 1999; Begum et al. 2013). In addition, this transition between the two phases differs significantly among species (Farrar \& Evert 1997b; Lachaud et al. 1999). Figure 2 shows the most commonly used terminology in relation to the dormancy and activity of the cambium on the example of Fagus sylvatica.

The ultrastructure of cambium cells differs significantly in its active and dormant state and can be seen in the different organisation, distribution, number and shape of the organelles (Farrar \& Evert 1997b; Lachaud et al. 1999; Rensing \& Samuels 2004) (Fig. 3). Most obvious are the differences in shape and size of the vacuoles, which are small, round, numerous and within a dense cytoplasm in dormant cells (Farrar \& Evert 1997a; Rensing \& Samuels 2004; Frankenstein et al. 2005; Prislan et al.2011). In general, the first divisions in spring occur at the end of a 1 to 4 week period characterised by changes in the vacuolar system following the resumption of cyclosis, i.e., the elongation of small vacuoles and their progressive fusion into one or two large vacuoles. Dividing cambial cells contain, among other elements, large vacuoles, rough ER (endoplasmic reticulum), numerous dictyosomes, which produce vesicles and lack storage products such as lipid droplets. The transition from activity to dormancy involves processes whereby large vacuoles fragment into a number of smaller ones, which intersperse throughout the cytoplasm. Rough ER is replaced by smooth ER and an accumulation of storage products takes place, the nature of which depends on the species (Fig. 3). Dictyosomes become fewer and mainly inactive (Farrar \& Evert 1997a,b; Lachaud et al. 1999; Rensing \& Samuels 2004; Prislan et al. 2011).

Several authors have reported that lipid droplets are present only in dormant cambium (Robards \& Kidwai 1969; Rao \& Dave 1983; Farrar \& Evert 1997b; Prislan et al . 2011). Amyloplasts (starch-containing plastids), however, are numerous in the active state and absent or rare in dormant cambium, as observed in different species (Itoh 1971; Farrar \& Evert 1997b; Begum et al. 2010a; Prislan et al. 2011). Begum et al. (2010a) pointed out that storage materials (e.g., lipid droplets and starch-containing plastids) are important for the dormancy and reactivation of cambium. During cambial dormancy, levels of starch might be low as a consequence of the breakdown of starch that is associated with the generation of energy for the development of cold hardiness (Pomeroy \& Siminovitch 1971; Timell 1986). Lipid droplets might be utilised as sources of energy for cell division and the biosynthesis of new cell wall material in the cambium (Begum et al.2010a).

Seasonal changes in the ultrastructure of cambial cells may depend on the tree species and sites. Dictyosomes, for example, were found to be active in the dormant period in Aesculus hippocastanum (Barnett 1992) and Pinus strobus (Srivastava \& O'Brien 1966). The appearance of different types of ER (tubular, vesicular or cisternal) in the cambium can also differ between active and dormant states (e.g., Rao \& Dave 1983; Farrar \& Evert 1997b) and among species (Srivastava \& O’Brien 1966; Barnett 1992). These differences can be species specific or can be attributed to differences in growth conditions, different methodological approaches etc. 
Seasonal changes of cambial cells are mainly examined in transverse sections; however, ultrastructural features during the cytokinesis of fusiform cambial cells must also be studied in the radial plane. Bailey (1919), for example, described in detail the process of cell divisions in Pinus strobus based on observation with light microscope. Although periclinal divisions are most common in cambium, little is known about their ultrastructure (Rensing et al. 2002).

In contrast to cells in primary meristems, the length of cambial cells can be 500 times larger than their diameter, so the course of divisions along the axis is slightly different (Rensing et al. 2002; Samuels et al. 2006). During cambial cell cytokinesis, mitotic spindles separate chromosomes across the radial width/dimension of the cells. However, during cell plate growth, the formed phragmoplast divides axially into two parts. Both parts are surrounded by cytoplasm, representing so-called boluses, which migrate in opposite directions along the extended axis of the cell and form the new cell plate (Rensing et al. 2002).

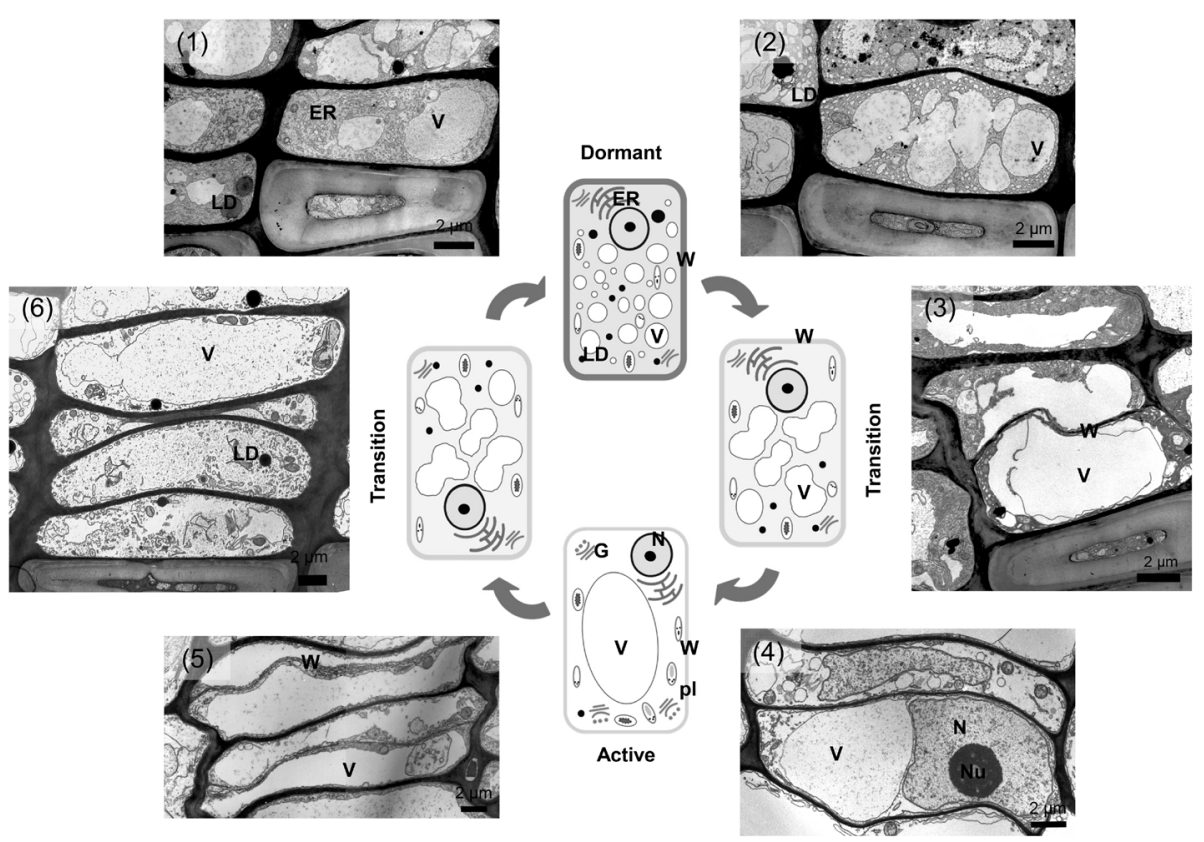

Figure 3. Schematic diagram of cytoplasmic changes occurring in cambial cells of temperate trees during a seasonal cycle. Actively dividing cell in spring or summer, with a large vacuole (V). Transition to rest in autumn; fragmentation of the vacuole (V) and thickening of the cell walls begins (W). Dormant cell in winter; numerous vacuoles become globular during the cessation of cyclosis; mostly smooth endoplasmic reticulum (ER), Golgi apparatus (G) with few secretory vesicles, numerous lipid droplets (LD). Transition to activity in late winter-early spring, showing elongation and fusion of vacuoles following the resumption of cyclosis, rough endoplasmic reticulum, active Golgi apparatus. Nucleus $(\mathrm{N})$ with nucleolus $(\mathrm{Nu})$, plasmodesma $(\mathrm{pl})$. - (1-6) Micrographs showing transverse sections of Fagus sylvatica cambial cells in different stages of activity; $(1,2)$ dormant cells, (3) transition from dormant to active state, $(4,5)$ active cells and (6) transition from active to dormant state. 
Relatively little is known about the structural changes of the cambial cell wall during the transition from the dormant to the active state. In the majority of tree species, the walls of dormant cambial cells are thicker than those in active cells (Larson 1994). Chen et al. (2010) found that dormant cambial cell walls of Populus tomentosa displayed a multi-layered structure, denser fibril network, smaller pore size and fewer crosslinks between microfibrils than active cambial cell walls. Chaffey et al. (1998) suggested, based on observations of cambial seasonal changes in Aesculus hippocastanum, that cell-wall thickening at the onset of cambial dormancy should be considered to be secondary thickening and that selective lysis of this secondary wall layer during cambial reactivation restores the thinner, primary wall around active cambial cells. A certain seasonal variability in the frequency of plasmodesmata was also observed in Populus nigra (Fuchs et al. 2010).

\section{OBSERVATION OF CAMBIAL STRUCTURE WITH LIGHT (LM) AND TRANSMISSION ELECTRON MICROSCOPY (TEM)}

Processing plant tissues for TEM can be divided into six major steps: (I) specimen acquisition from a living tree, (II) trimming of the specimen, (III) fixation, (IV) dehydration, (V) infiltration and (VI) embedding (Bozzola \& Russell 1999). Standard techniques for wood formation studies are clearly outlined in "Wood formation in trees - cell and molecular biology techniques", edited by Chaffey (2002); from light microscopy to advanced electron microscopy techniques. Recent advances in methodologies for studying the structure of cambium and developing xylem tissue are especially pronounced in the field of tissue fixation; Rensing et al. (2002) precisely presented differences in the observation of cambial cells when using conventional chemical fixation or cryofixation and substitution. We demonstrated that combining LM and conventional TEM can provide detailed information on cambial phenology and seasonal ultra-structural changes in cambial cells of Fagus sylvatica growing at forest sites with different weather conditions (Prislan et al. 2011).

\section{Sample collection}

In wood/phloem formation studies at cellular and ultrastructural levels, tissues containing phloem, cambium and outer xylem are collected from living trees. The time intervals of samplings should be relatively short, i.e., one to two weeks, and depend on the goal of the study. For observations of the seasonal dynamics of different phases of wood formation, small micro-cores are usually collected with tools causing minor damage on tree stems. A Trephor tool has recently become widely used for sampling (Rossi et al.2006) but an increment puncher (Forster et al.2000) and injection needles (Jyske et al.2011) are also used. Due to the small size of wounds caused by these tools, repeated sampling on the same tree can be performed in more than one growing season, without affecting the vitality of the tree. However, micro-cores (e.g., diameter c. $2 \mathrm{~mm}$ and length c. $10 \mathrm{~mm}$ ) are difficult to handle and they can be easily damaged or the tissue can be affected. They are therefore not suitable for ultrastructural observations, thus sampling larger blocks of intact tissues using a chisel and knife, as described by Uggla and Sundberg (2002) or Gričar et al. (2007b), should be preferred. 


\section{Sample preparation and observation}

For light microscopic (LM) observations, microcores are first fixed in a solution, such as formalin-ethanol-acetic acid (FEA), dehydrated in a graded series of ethanol and clearing reagent (e.g. D-limonene) and infiltrated, as well as embedded in paraffin as described by Rossi et al. (2006). Various embedding media, such as glycolmethacrylate (Oberhuber \& Gruber 2010) or polyethyleneglycol (Liang et al. 2009), are also used (Table 1). Cross sections of 8 to $10 \mu \mathrm{m}$ thickness are prepared with a rotary microtome and then stained with safranin and astra blue (e.g., Van der Werf et al. 2007; Gričar et al. 2007a), or cresyl violet acetate (e.g., Antonova \& Stasova 1993; Deslauriers et al.2003). For preparation of permanent sections, embedding media such as Euparal (e.g., Gričar et al. 2005) or Canada balsam (e.g., Moser et al. 2010) are used. Using LM, cambial phenology (onset and cessation of cambial cell production), phases of

Table 1. Overview of sample processing procedures for different tissues and microscopy techniques.

\begin{tabular}{|c|c|c|}
\hline & Light microscopy (LM) & Transmission electron microscopy (TEM) \\
\hline $\begin{array}{l}\text { Use in wood } \\
\text { formation } \\
\text { studies }\end{array}$ & $\begin{array}{l}\text { Cambial phenology, } \\
\text { xylem/phloem differentiation, } \\
\text { seasonal dynamics of growth } \\
\text { ring formation. }\end{array}$ & $\begin{array}{l}\text { Seasonal changes in cambial ultrastruc- } \\
\text { ture (structure of living tissues should } \\
\text { be preserved). }\end{array}$ \\
\hline \multirow[t]{2}{*}{ Fixation } & \multirow[t]{2}{*}{$\begin{array}{l}\text { - Formalin-ethanol-acetic acid } \\
\text { solution (FEA) (Gričar } \text { et al. } \\
\text { 2007b); } \\
\text { - Ethanol, propionic acid and } \\
\text { formaldehyde solution } \\
\text { (Oberhuber \& Gruber 2010); } \\
\text { - Water and ethanol solution } \\
\text { (Lupi } \text { et al. 2010). }\end{array}$} & $\begin{array}{l}\text { Primary fixative: } \\
\text { - Mixture of 5\% glutaraldehyde, } 8 \% \\
\text { paraformaldehyde and 0.3 M cacody- } \\
\text { late buffer) (Farrar \& Evert 1997b; } \\
\text { Frankenstein } \text { et al. 2005); } \\
\text { - Mixture of } 2.5 \% \text { glutaraldehyde in } \\
\text { 0.05 M phosphate buffer (pH 6.8) } \\
\text { (Rensing \& Samuels 2004). }\end{array}$ \\
\hline & & $\begin{array}{l}\text { Secondary fixative: } \\
\text { ( } 2 \% \text { aqueous osmium tetroxide solution). }\end{array}$ \\
\hline Dehydration & $\begin{array}{l}\text { Graded series of ethanol. } \\
\text { Clearing reagent: } \\
\text { - D-limonene (Gričar et al. } \\
\text { 2007a); } \\
\text { - Histosol (Lupi et al. 2010). }\end{array}$ & Acetone. \\
\hline $\begin{array}{l}\text { Infiltration / } \\
\text { embedding }\end{array}$ & $\begin{array}{l}\text { Embedding media: } \\
\text { - Paraffin (Rossi et al. 2006); } \\
\text { - Glycolmethacrylate } \\
\text { (Oberhuber \& Gruber 2010); } \\
\text { - Polyethyleneglycol (Liang } \\
\text { et al. 2009). }\end{array}$ & Epoxy resin (Spurr 1969). \\
\hline Cutting & $\begin{array}{l}\text { Rotary microtome (sections } \\
8-12 \mu \mathrm{m}) \text {. }\end{array}$ & Ultra microtome (sections $90-100 \mathrm{~nm}$ ). \\
\hline Staining & $\begin{array}{l}\text { - Safranin and astrablue } \\
\text { (Gričar et al. 2007b); } \\
\text { - Cresyl violet acetate } \\
\text { (Deslauriers et al. (2003). }\end{array}$ & Uranyl acetate and lead citrate. \\
\hline
\end{tabular}


differentiation of xylem / phloem cells and seasonal dynamics of xylem/phloem growth ring formation can be observed (e.g., Schmitt et al. 2000; Gričar 2007; Seo et al.2008; Rossi et al. 2011; Michelot et al. 2012) (Table 1).

Larger blocks of intact tissue are commonly collected for ultrastructural observations by transmission electron microscopy (TEM), because of easier manipulation and to prevent deformation of the tissue and the occurrence of artefacts. Afterwards, sample size is reduced to less than $2 \mathrm{~mm}$ in thickness in order to ensure adequate fixation (Bozzola \& Russell 1999). Samples for observation of ultrastructural seasonal changes in cambial cells are fixed for one day in a mixture of $5 \%$ glutaraldehyde, $8 \%$ paraformaldehyde and $0.3 \mathrm{M}$ cacodylate buffer. They are then washed in $0.1 \mathrm{M}$ cacodylate buffer $(\mathrm{pH} 7.3)$ and post-fixed for one additional day in a $2 \%$ aqueous osmium tetroxide solution. They are again washed in 0.1 M cacodylate buffer ( $\mathrm{pH} 7.3$ ), dehydrated through a graded series of acetone and finally embedded in Spurr's (1969) epoxy resin. Phosphate buffer is often used instead of cacodylate buffer (Rensing \& Samuels 2004) (Table 1). Ultrathin transverse sections $(90-100 \mathrm{~nm})$ of cambium are then prepared. Sections are placed on copper grids and stained with uranyl acetate and lead citrate and examined with a TEM at an accelerating voltage of 80 or $100 \mathrm{kV}$ (e.g., Farrar \& Evert 1997b; Frankenstein et al. 2005; Prislan et al. 2011). Seasonal changes in the cytoplasm of cambial cells can be observed by TEM (Farrar \& Evert 1997b; Rensing \& Samuels 2004), as well as changes in the architecture of cambial cell walls (Chen et al. 2010).

\section{ENVIRONMENTAL REGULATION OF CAMBIAL ACTIVITY EXEMPLIFIED BY FAGUS SYLVATICA}

We illustrate this section with our own examination of cambial phenology in Fagus sylvatica at two sites in Slovenia, central Europe, with different elevations and weather regimes. The low elevation forest site (400 $\mathrm{m}$ a.s.1.) has a mean annual temperature (MAT) of $11.3^{\circ} \mathrm{C}$ and $1565 \mathrm{~mm}$ of annual precipitation and the high elevation site $(1200 \mathrm{~m}$ a.s.1.) has $6.6^{\circ} \mathrm{C}$ MAT and slightly higher precipitation (Prislan et al. 2011; 2013).

The two sites were carefully selected based on previous investigations in beech and climatic factors in Slovenia involving tree-ring variation and climate (Di Filippo et al. 2007; Čufar et al. 2008), leaf phenology (Čufar et al. 2012), climatic situation and trends (De Luis et al. 2012), and connection of tree-ring variation, leaf phenology, cambial activity and wood formation and climate (Čufar et al. 2008; Prislan et al. 2013). Thus, the selected locations are representative for growth of beech at low and high elevations in Slovenia.

Dormant cambium contained 4 to 5 cell layers at both sites, whereas active cambium had a slightly higher number of cell layers at the low elevation site (around 11) than at the high elevation site (around 8) (Prislan et al. 2011). At the high elevation site, the onset of cambial cell production occurred one month later (in the middle of May) than at the low elevation site (Prislan et al.2013). Maximal cell productivity was observed at the high elevation site around the summer solstice and at the low elevation site at the beginning of June. Cell production ceased at the beginning of August at the high elevation site and at the end of August at the low elevation site (Fig. 4) (Prislan et al.2011). 

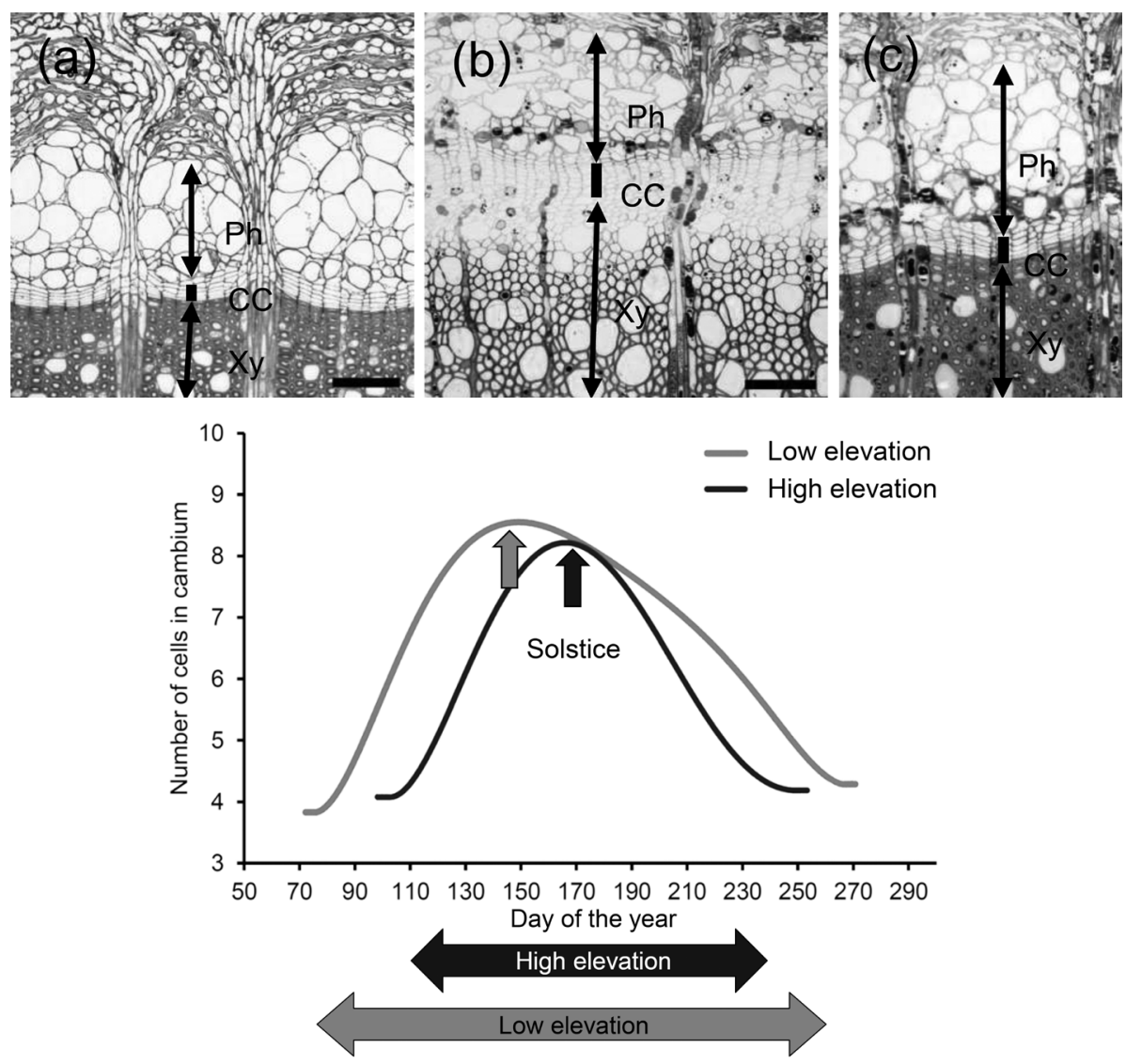

Figure 4. Light micrographs showing the cambium of Fagus sylvatica (a) in the dormant state before the onset and (c) after the cessation of cambial activity and (b) active cambium. The graph shows seasonal changes in the number of cells in the cambium at high and low elevation sites (d). Arrowheads indicate the timing of maximal cambial productivity; at the high elevation site this occurred, around the summer solstice, at the low elevation site in the beginning of June. Arrows show the duration of cambial cell production.

Our study demonstrated that the duration of the growing season is inversely proportional to the altitude (in temperate regions); the onset of cell production at a high elevation starts later and ceases earlier (Prislan et al. 2013). However, this conclusion is preliminary and for its generalisation about the effect of elevation on cambial phenology further studies should be performed with the inclusion of additional sites. The shorter duration of cambial activity at the higher sites can be ascribed to the generally lower air and soil temperatures, as well as a longer period of snow cover, since such conditions are limiting for physiological processes, particularly at the beginning of the vegetation period, as reported for instance by Kirdyanov et al. (2003) and Moser et al. (2010). 
The cambium is mainly susceptible to environmental signals during the active period and archives them in the wood and bark structure (e.g., Frankenstein et al. 2005; Gričar \& Čufar 2008).

In temperate and cool regions, temperature and photoperiod are important external factors of the initiation of cambial reactivation and xylem differentiation (Li et al. 2009; Begum et al. 2013). Deslauriers et al. (2008) studied cambial phenology in Pinus leucodermis at high altitudes in Italy and showed that temperatures in spring are the main factor driving the onset of cell production. Rossi et al. (2008) tried to define temperature thresholds for the onset and cessation of cambial cell production for conifers from different latitudes of boreal and temperate regions. The presented mean critical temperatures, which varied by around $8^{\circ} \mathrm{C}$, were significant for the onset of cell production; however, mean critical temperatures for cessation (around $14{ }^{\circ} \mathrm{C}$ ) were not significant. Seo et al. (2011) monitored the intra-annual growth dynamics of pine trees (Pinus sylvestris) in northern Scandinavia, with diverging results; at some sites, wood formation was mainly positively correlated with temperature, whereas such a positive correlation was missing at other sites or it was even negative. Furthermore, we also showed that the temperatures prior to the occurrence of relevant cambial phenological phases, together with calculated growing degree days, significantly differed at the low and high elevation beech sites in Slovenia, indicating that phenological events are not in simple relationship with climate, or at least not in agreement with year-to-year variations in weather. The accumulated heat units (growing degree days - GGDs) at the beginning of cambial activity, for instance, were higher in the lowland (around $147^{\circ} \mathrm{D}$ ) than at higher elevations (around $72^{\circ} \mathrm{D}$ ) (Prislan et al. 2013).

Seasonal changes in the ultrastructure of cambial cells studied along the altitudinal gradient are rare. We showed by TEM that processes in cambial cells that are related to seasonal changes are similar regardless of the elevation; only the timings of individual events differ and are generally delayed at higher elevations at the onset of the growing season.

At the end of the growing season, the sequence of changes in the cambium was just the opposite; the transition from active to dormant state started first in the cambial cells of Fagus sylvatica from the higher elevation (Prislan et al.2011).

\section{LM AND TEM, COMPLEMENTARY APPROACHES TO STUDYING CAMBIUM SEASONALITY}

This section is also illustrated by our own results obtained by a combination of TEM and LM studies of Fagus sylvatica from two elevations in Slovenia. TEM observations revealed that cytoplasmic changes in cambial cells during the seasonal cycle occur much earlier (about one month) than was observed at the cellular level with LM (Prislan et al. 2011).

The results are affected by: 1) the media used for tissue fixation and embedding, as well as 2) the thickness of sections and microscope resolution/magnification. A fixative such as FAA (formaldehyde, ethanol and acetic acid) is commonly used in wood formation studies (observing cambial phenology and xylem growth ring formation 
dynamic), whereby sections are observed with LM. The main disadvantage of FAA is insufficient preservation of the cytoplasm in cambial cells. Reactivation of the cambium at the cellular level is usually histologically defined by an increased number of cambial cells and the occurrence of newly formed xylem and phloem cells in early developmental stages. With LM, it is possible to detect cambial production based on the number of newly formed cells at a certain time interval, as well as differentiation of xylem and phloem cells; however, cytoplasmic changes associated with the seasonal cycle of the cambium cannot be recognised (Prislan et al. 2011).

Observations on a sub-cellular level are also possible with LM (Fig. 5), when using primary fixation with glutaraldehyde and phosphate buffer and secondary fixation in osmium tetroxide (usually used for TEM observations), as demonstrated by Bailey (1919) or Begum et al. (2010b), who were able to observe new cell plates. Similarly, Rensing and Samuels (2004) were able to observe differences in the arrangement of vacuoles between dormant and active cambial cells.

TEM, with its high resolution and magnification (Goodhew et al. 2000), in combination with proper fixation of the cambial tissue, i.e., preservation of cytoplasm, allows the observation of seasonal changes in the distribution and size of cell organelles (Fig. 5). This is particularly important during the transition of cambial cells to active or dormant state, when the number of cell layers is unchanged but ultra-structural changes (in the form of dictyosome activity, changes related to endoplasmic reticulum, etc.) are already occurring.

Consequently, different criteria for cambial reactivation are used with different sample preparation and microscopy techniques (resolutions), as was already stressed by Frankenstein et al. (2005). Begum et al. (2013), e.g., called the period from late winter to late spring, when new cell plates are formed in the cambium, "cambial reactivation". In our TEM study (Prislan et al. 2011), changes in the ultrastructure of cambial cells were observed prior to the formation of new cell walls, and the cambium can thus be considered to be active as well in this earlier stage. When using different fixation, embedding and microscopy techniques and criteria, the established dates of cambial seasonality can vary. However, a combination of different approaches enables the activity and productivity of cambium to be precisely followed.

\section{CONCLUSIONS}

Examination of cambial tissue using different microscopic levels revealed that different criteria are used to define the onset of cambial reactivation; the results of different studies are therefore not simply comparable. The terminology should thus be adjusted and standardised to avoid disagreement among different research groups when comparing data, as was already stressed by Frankenstein et al. (2005).

Complementary methodologies can assure a better understanding of relations between physiological processes in the cambium and climate with regard to predictions of tree responses to anticipated climate change. The presented facts can help in future cambial studies, particularly when the results of different studies using different techniques must be compared. 


\section{ACKNOWLEDGEMENTS}

This work was supported by the Slovenian Research Agency, young researchers' program (Peter Prislan) programs P4-0015 and P4-0107, and by the LLP ERASMUS bilateral agreement between the University of Ljubljana and the University of Hamburg. The cooperation among international partners was supported by the COST Action FP1106, STReESS. The authors gratefully acknowledge the help of Professor Jasna Štrus and her team at the Department of Biology, Biotechnical Faculty, University of Ljubljana. We thank Tanja Potsch, Dr. Magda Tušek Žnidarič and Dr. Nada Žnidaršič for their immense help in the laboratory.

\section{REFERENCES}

Antonova GF \& Stasova VV. 1993. Effects of environmental factors on wood formation in Scots pine stems. Trees 7: 214-219.

Bailey IW. 1919. Phenomena of cell division in the cambium of arborescent gymnosperms and their cytological significance. Proceedings of the National Academy of Sciences of the USA 5: 283-285.

Barnett JR. 1992. Reactivation of the cambium in Aesculus hippocastanum L. - a transmission electron microscopy study. Ann. Bot. 70: 169-177.

Begum S, Nakaba S, Oribe Y, Kubo T \& Funada R. 2010a. Changes in the localization and levels of starch and lipids in cambium and phloem during cambial reactivation by artificial heating of main stems of Cryptomeria japonica trees. Ann. Bot. 106: 885-895.

Begum S, Nakaba S, Oribe Y, Kubo T \& Funada R. 2010b. Cambial sensitivity to rising temperatures by natural condition and artificial heating from late winter to early spring in the evergreen conifer Cryptomeria japonica. Trees 24: 43-52.

Begum S, Nakaba S, Yamagishi Y, Oribe Y \& Funada R. 2013. Regulation of cambial activity in relation to environmental conditions: understanding the role of temperature in wood formation of trees. Physiol. Plantarum 147: 46-54.

Bozzola JJ \& Russell LD. 1999. Electron microscopy: principles and techniques for biologists. Jones and Bartlett Publishers, Boston.

Callado CH, Roig FA, Tomazello-Filho M \& Barrow CF. 2013. Cambial growth periodicity studies of South American woody species - A review. IAWA J. 34: 213-230.

Catesson A-M. 1994. Cambial ultrastructure and biochemistry: changes in relation to vascular tissue differentiation and the seasonal cycle. Int. J. Plant Sci. 155: 251-261.

Chaffey NJ. 2002. Wood formation in trees: cell and molecular biology techniques. Taylor \& Francis, London, New York.

Chaffey NJ, Barlow PW \& Barnett JR. 1998. A seasonal cycle of cell wall structure is accompanied by a cyclical rearrangement of cortical microtubules in fusiform cambial cells within taproots of Aesculus hippocastanum (Hippocastanaceae). New Phytol. 139: 623-635.

Chen HM, Han JJ, Cui KM \& He XQ. 2010. Modification of cambial cell wall architecture during cambium periodicity in Populus tomentosa Carr. Trees 24: 533-540.

Costa MS, de Vasconcellos TJ, Barros CF \& Callado CH. 2013. Does growth rhythm of a widespread species change in distinct growth sites? IAWA J. 34: 498-509.

Čufar K, De Luis M, Saz M, Črepinšek Z \& Kajfež-Bogataj L. 2012. Temporal shifts in leaf phenology of beech (Fagus sylvatica) depend on elevation. Trees 26: 1091-1100.

Čufar K, Prislan P, De Luis M \& Gričar J. 2008. Tree-ring variation, wood formation and phenology of beech (Fagus sylvatica) from a representative site in Slovenia, SE Central Europe. Trees 22: 749-758. 
De Luis M, Čufar K, Saz M, Longares L, Ceglar A \& Kajfež-Bogataj L. 2012. Trends in seasonal precipitation and temperature in Slovenia during 1951-2007. Reg. Environ. Change. DOI: $10.1007 / \mathrm{s} 10113-012-0365-7$.

Deslauriers A, Morin H \& Begin Y. 2003. Cellular phenology of annual ring formation of Abies balsamea in the Quebec boreal forest (Canada). Can. J. Forest Res. 33: 190-200.

Deslauriers A, Rossi S, Anfodillo T \& Saracino A. 2008. Cambial phenology, wood formation and temperature thresholds in two contrasting years at high altitude in southern Italy. Tree Physiol. 28: 863-871.

Di Filippo A, Biondi F, Čufar K, De Luis M, Grabner M, Maugeri M, Presutti Saba E, Schirone B \& Piovesan G. 2007. Bioclimatology of beech (Fagus sylvatica L.) in the Eastern Alps: spatial and altitudinal climatic signals identified through a tree-ring network. J. Biogeogr. 34: $1873-1892$.

Evert RF. 2006. Esau's Plant anatomy. Meristems, cells, and tissues of the plant body: their structure, function, and development. Wiley-Interscience, Hoboken, New Jersey.

Farrar JJ \& Evert RF. 1997a. Ultrastructure of cell division in the fusiform cells of the vascular cambium of Robinia pseudoacacia. Trees 11: 203-215.

Farrar JJ \& Evert RF. 1997b. Seasonal changes in the ultrastructure of the vascular cambium of Robinia pseudoacacia. Trees 11: 191-202.

Forster T, Schweingruber FH \& Denneler B. 2000. Increment puncher - A tool for extracting small cores of wood and bark from living trees. IAWA J. 21: 169-180.

Frankenstein C, Eckstein D \& Schmitt U. 2005. The onset of cambium activity - A matter of agreement? Dendrochronologia 23: 57-62.

Fromm J. 2013. Xylem development in trees: From cambial divisions to mature wood cells. In: Fromm J (ed.), Cellular aspects of wood formation: 3-39. Springer, Berlin, Heidelberg.

Fuchs M, van Bel AJE \& Ehlers K. 2010. Season-associated modifications in symplasmic organization of the cambium in Populus nigra. Ann. Bot. 105: 375-387.

Goodhew PJ, Humphreys J \& Beanland R. 2000. Electron microscopy and analysis. Taylor and Francis, London, New York.

Gričar J. 2007. Xylo- and phloemogenesis in silver fir (Abies alba Mill.) and Norway spruce (Picea abies (L.) Karst.). Slovenian Forestry Institute, Ljubljana.

Gričar J \& Čufar K. 2008. Seasonal dynamics of phloem and xylem formation in silver fir and Norway spruce as affected by drought. Russ. J. Plant Physiol. 55: 538-543.

Gričar J, Čufar K, Oven P \& Schmitt U. 2005. Differentiation of terminal latewood tracheids in silver fir trees during autumn. Ann. Bot. 95: 959-965.

Gričar J, Zupančič M, Čufar K, Koch G, Schmitt U \& Oven P. 2006. Effect of local heating and cooling on cambial activity and cell differentiation in the stem of Norway spruce (Picea abies). Ann. Bot. 97: 943-951.

Gričar J, Zupančič M, Čufar K \& Oven P. 2007a. Wood formation in Norway spruce (Picea abies) studied by pinning and intact tissue sampling method. Wood Res. 52: 1-10.

Gričar J, Zupančič M, Čufar K \& Oven P. 2007b. Regular cambial activity and xylem and phloem formation in locally heated and cooled stem portions of Norway spruce. Wood Sci. Technol. 41: 463-475.

Itoh T. 1971. On the ultrastructure of dormant and active cambium of conifers. Bull. Wood Res. Inst. Kyoto Univ. 51: 33-45.

Jyske T, Manner M, Mäkinen H, Nöjd P, Peltola H \& Repo T. 2011. The effects of artificial soil frost on cambial activity and xylem formation in Norway spruce. Trees 26: 1-15.

Kirdyanov A, Hughes M, Vaganov E, Schweingruber F \& Silkin P. 2003. The importance of early summer temperature and date of snow melt for tree growth in the Siberian Subarctic. Trees 17: 61-69. 
Lachaud S, Catesson AM \& Bonnemain JL. 1999. Structure and functions of the vascular cambium. Life Sci. 322: 633-650.

Larson PR. 1994. The vascular cambium: development and structure. Springer, Berlin.

Li WF, Ding Q, Chen JJ, Cui KM \& He XQ. 2009. Induction of PtoCDKB and PtoCYCB transcription by temperature during cambium reactivation in Populus tomentosa Carr. J. Exp. Bot. 60: 2621-2630.

Liang EY, Eckstein D \& Shao XM. 2009. Seasonal cambial activity of relict Chinese pine at the northern limit of its natural distribution in north China - Exploratory results. IAWA J. 30: $371-378$.

Lupi C, Morin H, Deslauriers A \& Rossi S. 2010. Xylem phenology and wood production: resolving the chicken-or-egg dilemma. Plant Cell Environ. 33: 1721-1730.

Mauseth JD. 2009. Botany: An introduction to plant biology. Jones \& Bartlett Publ., Sudbury.

Mellerowicz EJ, Baucher M, Sundberg B \& Boerjan W. 2001. Unravelling cell wall formation in woody dicot stem. Plant Mol. Biol. 47: 239-274.

Michelot A, Simard S, Rathgeber C, Dufrêne E \& Damesin C. 2012. Comparing the intra-annual wood formation of three European species (Fagus sylvatica, Quercus petraea and Pinus sylvestris) as related to leaf phenology and non-structural carbohydrate dynamics. Tree Physiol. 32: 1033-1045.

Moser L, Fonti P, Büntgen U, Esper J, Luterbacher J, Franzen J \& Frank D. 2010. Timing and duration of European larch growing season along altitudinal gradients in the Swiss Alps. Tree Physiol. 30: 225-233.

Oberhuber W \& Gruber A. 2010. Climatic influences on intra-annual stem radial increment of Pinus sylvestris (L.) exposed to drought. Trees 24: 887-898.

Plomion C, LeProvost G \& Stokes A. 2001. Wood formation in trees. Plant Physiol. 127: $1513-1523$.

Pomeroy MK \& Siminovitch D. 1971. Seasonal cytological changes in secondary phloem parenchyma cells in Robinia pseudoacacia in relation to cold hardiness. Can. J. Bot. 49: 787-795.

Prislan P, Gričar J, De Luis M, Smith KT \& Čufar K. 2013. Phenological variation in xylem and phloem formation in Fagus sylvatica from two contrasting sites. Agr. Forest Meteorol. 180: $142-151$.

Prislan P, Schmitt U, Koch G, Gričar J \& Čufar K. 2011. Seasonal ultrastructural changes in the cambial zone of beech (Fagus sylvatica) grown at two different altitudes. IAWA J. 32: $443-459$.

Rao KS \& Dave YS. 1983. Ultrastructure of active and dormant cambial cells in teak (Tectona grandis L.f.). New Phytol. 93: 447-456.

Rathgeber CBK, Rossi S \& Bontemps J-D. 2011. Cambial activity related to tree size in a mature silver-fir plantation. Ann. Bot. 108: 429-438.

Rensing KH \& Samuels AL. 2004. Cellular changes associated with rest and quiescence in winter-dormant vascular cambium of Pinus contorta. Trees 18: 373-380.

Rensing KH, Samuels AL \& Savidge RA. 2002. Ultrastructure of vascular cambial cell cytokinesis in pine seedlings preserved by cryofixation and substitution. Protoplasma 220: 39-49.

Riding RT \& Little CHA. 1984. Anatomy and histochemistry of Abies balsamea cambial zone cells during the onset and breaking of dormancy. Can. J. Bot. 62: 2570-2579.

Risopatron JPM, Sun YQ \& Jones BJ. 2010. The vascular cambium: molecular control of cellular structure. Protoplasma 247: 145-161.

Robards AW \& Kidwai P. 1969. A comparative study of the ultrastructure of resting and active cambium of Salix fragilis L. Planta 84: 239-224.

Rossi S, Anfodillo T \& Menardi R. 2006. Trephor: a new tool for sampling microcores from tree stems. IAWA J. 27: 89-97. 
Rossi S, Deslauriers A, Gričar J, Seo JW, Rathgeber CWG, Anfodillo T, Morin H, Levanič T, Oven P \& Jalkanen R. 2008. Critical temperatures for xylogenesis in conifers of cold climates. Global Ecol. Biogeogr. 17: 696-707.

Rossi S, Morin H \& Deslauriers A. 2011. Multi-scale influence of snowmelt on xylogenesis of black spruce. Arctic, Antarctic, and Alpine Research 43: 457-464.

Samuels AL, Kaneda M \& Rensing KH. 2006. The cell biology of wood formation: from cambial divisions to mature secondary xylem. Can. J. Bot. 84: 631-639.

Savidge RA. 1996. Xylogenesis, genetic and environmental regulation - a review. IAWA J . 17: 269-310.

Savidge RA. 2000a. Intrinsic regulation of cambial growth. J. Plant Growth Regul. 20: 52-77.

Savidge RA. 2000b. Biochemistry of seasonal cambial growth and wood formation - an overview of the challenges. In: Savidge RA, Barnett JR, Napier R \&Biggs A (eds.), Cell and molecular biology of wood formation: 1-30. BIOS Scientific Publishers Ltd, Oxford, UK.

Schmitt U, Möller R \& Eckstein D. 2000. Seasonal wood formation dynamics of beech (Fagus sylvatica L.) and black locust (Robinia pseudoacacia L.) as determined by the "pinning" technique. J. Appl. Bot. 74: 10-16.

Seo JW, Eckstein D, Jalkanen R, Rickebusch S \& Schmitt U. 2008. Estimating the onset of cambial activity in Scots pine in northern Finland by means of the heat-sum approach. Tree Physiol. 28: 105-112.

Seo JW, Eckstein D, Jalkanen R \& Schmitt U. 2011. Climatic control of intra- and interannual wood-formation dynamics of Scots pine in northern Finland. Environ. Exp. Bot. 72: 422-431.

Spurr AR. 1969. A low viscosity embedding medium for electron microscopy. J. Ultrastruct. Res. 26: 31-43.

Srivastava LM \& O'Brien TP. 1966. On the ultrastructure of cambium and its vascular derivatives. I. Cambium of Pinus strobus L. Protoplasma 61: 257-276.

Timell TE. 1986. Formation of compression wood. In: (ed.), Compression wood in gymnosperms 1: 623-636. Springer-Verlag, Berlin.

Uggla C, Mellerowicz EJ \& Sundberg B. 1998. Indole-3-acetic acid controls cambial growth in Scots pine by positional signaling. Plant Physiol. 117: 113-121.

Uggla C \& Sundberg B. 2002. Sampling of cambial region tissues for high resolution analysis. In: Chaffey N (ed.), Wood formation in trees. Cell and molecular biology techniques: 215-228. Taylor \& Francis, London, New York.

Ursache R, Nieminen K \& Helariutta Y. 2013. Genetic and hormonal regulation of cambial development. Physiol. Plantarum 147: 36-45.

Van der Werf GW, Sass-Klaassen U \& Mohren GMJ. 2007. The impact of the 2003 summer drought on the intra-annual growth pattern of beech (Fagus sylvatica L.) and oak (Quercus robur L.) on a dry site in the Netherlands. Dendrochronologia 25: 103-112.

Wodzicki TJ. 2001. Natural factors affecting wood structure. Wood Sci. Tech. 35: 5-26.

Zimmermann HM \& Brown CL. 1971. Trees structure and function. Springer, Berlin, Heidelberg, New York.

Accepted: 27 August 2013 